\title{
Using "Digital Black Hole" to Help Student in Learning Arithmetic and Enhance Students' Interest in Learning
}

\author{
Jihe Chen ${ }^{1}$, Ying Zhou ${ }^{2}$ Qiulian Zhao ${ }^{3}$ \\ 1,2 Department of Mathematics and Statistics, Guangxi Normal University, China \\ ${ }^{3}$ Pingguo High School Affiliated to Beijing Normal University, China \\ zhouying66@mailbox.gxnu.edu.cn
}

\begin{abstract}
For most students, mathematics is difficult, boring, and not fun. However, mathematics is of great help in terms of academic performance and the development of students' calculation ability and abstract logical thinking. So how to make students like mathematics? How to improve students' mathematical ability? In response to these two doubts, this article designed the following teaching links based on HPM. The research method in this research is descriptive qualitative by describing the lesson plan on arithmetic material. The sample and population were grade 3, Elementary school, in Guilin, China. The results showed that in the real class, it was found that students were very interested in the "Digital Black Hole" game, their mathematical calculation ability and the ability to find problems All have improved a lot. This shows that under the guidance of HPM, eliciting mathematics teaching through mathematics culture can help increase students' interest in mathematics, and students are also more aware that there are many magical relationships between numbers and numbers, which are worthy of us. Go explore and discover.
\end{abstract}

Keywords: Digital Black Hole, Interest In Learning, Arithmetic

\begin{abstract}
Abstrak
Bagi kebanyakan siswa, matematika itu sulit, membosankan, dan tidak menyenangkan. Namun, matematika sangat membantu dalam hal kinerja akademik dan pengembangan kemampuan berhitung siswa dan pemikiran logika dan abstrak. Lantas bagaimana caranya agar siswa menyukai matematika? Bagaimana cara meningkatkan kemampuan matematika siswa? Menanggapi dua keraguan ini, artikel ini merancang tautan pengajaran berikut berdasarkan HPM dengan digital black hole. Metode penelitian pada penelitian ini adalah kualitatif deskriptive dengan menjabarkan lesson plan pada materi aritmatika. Sample dan populasi adalah anak kelas 3 di guilin, China. hasil penelitian menunjukkan bahwa Di kelas sebenarnya, ditemukan bahwa siswa sangat tertarik dengan permainan "Digital Black Hole", kemampuan berhitung matematis mereka dan kemampuan mencari masalah Semua telah meningkat pesat. Hal ini menunjukkan bahwa di bawah bimbingan HPM, memunculkan pengajaran matematika melalui budaya matematika dapat membantu meningkatkan minat siswa terhadap matematika, dan siswa juga semakin sadar bahwa ada banyak hubungan magis antara angka dan angka, yang berharga bagi kita. Jelajahi dan temukan.
\end{abstract}

Kata kunci: lubang hitam digital, minat belajar, aritmatika

Copyright (c) 2020 Jihe Chen, Ying Zhou, Qiulian Zhao

$\triangle$ Corresponding author: zhouying66@mailbox.gxnu.edu.cn

Email Address: zhouying66@mailbox.gxnu.edu.cn

Received 29 November 2020, Accepted 05 Desember 2020, Published 09 Desember 2020

\section{INTRODUCTION}

HPM is the relationship between the history of exponential science and mathematics education (Fachrudin et al., 2019; Feigenberg, 2002). It appeared as an academic research field since 1972. At the Second International Conference on Mathematics Education, the International Research Group on the Relationship between Mathematics History and Mathematics Teaching (HPM) was established. The goal of HPM research is to improve the level of mathematics education through the use of mathematical history. HPM focuses on the relationship between mathematics and other subjects, the history of mathematics and the cognitive development of students, the history of 
mathematics and the application of mathematics culture in teaching, etc.

Normally textbooks only pay attention to the logical structure of knowledge (Aditya, Wijaya, Dewi, \& Zulfah, 2020), and do not pay attention to the formation process and cultural background of knowledge. Students only know to learn all kinds of mathematics (Franestian, Suyanta, \& Wiyono, 2020; Izquierdo Álvarez, 2020), but they don't know why they want to learn (E.E. Rohaeti, Nurjaman, Sari, Bernard, \& Hidayat, 2019; Wijaya, Tang, \& Purnama, 2020; Wijaya, Ying, Chotimah, et al., 2020), let alone the secrets hidden behind mathematical knowledge. Therefore, with the help of HPM theory, we not only let students learn knowledge, but also help them understand the mathematics culture and enhance their interest in mathematics.

In elementary school, especially in the third and fourth grades (Brezovszky et al., 2019), the teacher usually shows the students several mathematical calculation formulas (Putri \& Zulkardi, 2018; Yuliani, Fuad, \& Ekawati, 2019), and then asks the students to summarize the formulas (Bernard \& Chotimah, 2018), or guides the students to ask some questions from some pictures for the students to Solve (Puloo, Juniati, \& Wijayanti, 2018; Wijaya, Ying, Chotimah, et al., 2020). For example, the Father has 5 yuan. He is going to buy basketball and football. A pencil is 0.8 yuan and a notebook is 0.5 yuan. Question (1) How much does Xiao Ming need to buy 3 pencils and 5 notebooks? (2) How many pencils or books can be bought with the money in Xiao Ming's hand? (3) What other mathematical problems can you ask? These questions are very boring in the eyes of students. They don't like buying books or pencils, they prefer to play games, and they like some challenging knowledge. However, in order to achieve the goal of strengthening students' arithmetical skills, teachers often have to follow the requirements of the textbook (Syahputra \& Utami, 2019), allowing students to perform a large number of addition and subtraction operations. So over time, most students lose interest in mathematics. Generally speaking, if you can follow the teacher's instructions, the students' calculation ability will be improved a lot (Ogbonnaya, 2019), but at the same time, they have lost interest in mathematics and did not realize the fun that mathematics brings to them. Therefore, it is necessary for us to use other methods to allow students to not only improve the level of addition and subtraction but also to keep students interested in mathematics.

At the elementary school level, most students have weak calculation skills (Angganing, 2011; Siregar, 2017). Although they know basic addition and subtraction operations, they are not very proficient in three-digit and four-digit addition and subtraction calculations. And the students think mathematics especially the numbers are boring and meaningless. However, students' calculation ability directly affects their mathematics scores and their confidence in learning mathematics. Many operations are required in mathematics learning, and students also need to deepen the relationship between numbers and numbers through operations. HPM can build a bridge for students to learn mathematics and feel the charm of numbers, combine learning with interest, and help students learn better. 
Meaningful learning is not about solving problems, but about finding problems and thinking about them (Euis Eti Rohaeti, 2010; Sari, Mardiyana, \& Pramudya, 2020). but the teacher's job is to create an interesting learning atmosphere (Wijaya, Ying, Chotimah, et al., 2020; Wijaya, Ying, \& Purnama, 2020), and they also had more reasons for mathematics. Finally, the feelings of the learning process are once again elevated to the students' emotional attitudes and values, so that students can feel the wonderful world of mathematics with a feeling of awe, aesthetics, and yearning.

\section{METHOD}

This research is descriptive qualitative by describing the lesson plan on arithmetic material. Researchers designed lesson plans on arithmetic material. The sample of this research is the thirdgrade students. They have learned the rules of addition and subtraction and multi-digit addition and subtraction. The third-grade students are more interested in games. First, tell them news about numbers and use stories about math culture to arouse students' curiosity. Then let them make calculations according to certain rules like playing a game, see if they can get the conclusion of the story, and improve their ability to verify mathematical knowledge. Then, show other mathematical knowledge and guide students to explore other secrets between numbers and numbers in mathematical games. In other words, when the two-digit black hole is explored, students will naturally have a lot of curiosity: Are there other digital black holes? How was the digital black hole discovered? Why is this? Therefore, the teacher introduced some other types of digital black holes along the way, allowing students to expand their imagination and thinking space again. When the get out of class is about to end, students still want to continue their studies.

\section{RESULTS AND DISCUSSION}

"Digital Black Hole" teaching process

Show students the story of mathematics. One day in 1976, the "Washington Post" reported a piece of mathematics news: People were caught in an infinite loop of mathematics games. The rules of the game are like this: choose a natural number arbitrarily, if it is an even number, Divide by 2, and if it is odd, multiply it by 3 and add 1 . Repeat the above calculations continuously for the result obtained, and the final result is always the same.

Teacher: Do students like to play games? Today we will play a game about numbers.

teacher: Do you believe the conclusion of this story, students? Can you try to calculate the final result?

Mathematics questions are drawn from the mathematics story. Questions in the form of stories are very interesting for children. At the beginning of learning, you should focus on basic concepts rather 
than giving formulas directly to students. This calculation is relatively simple and easy to perform, and can also stimulate students' interest. Next, the teacher leads the students to verify, such as number 5.

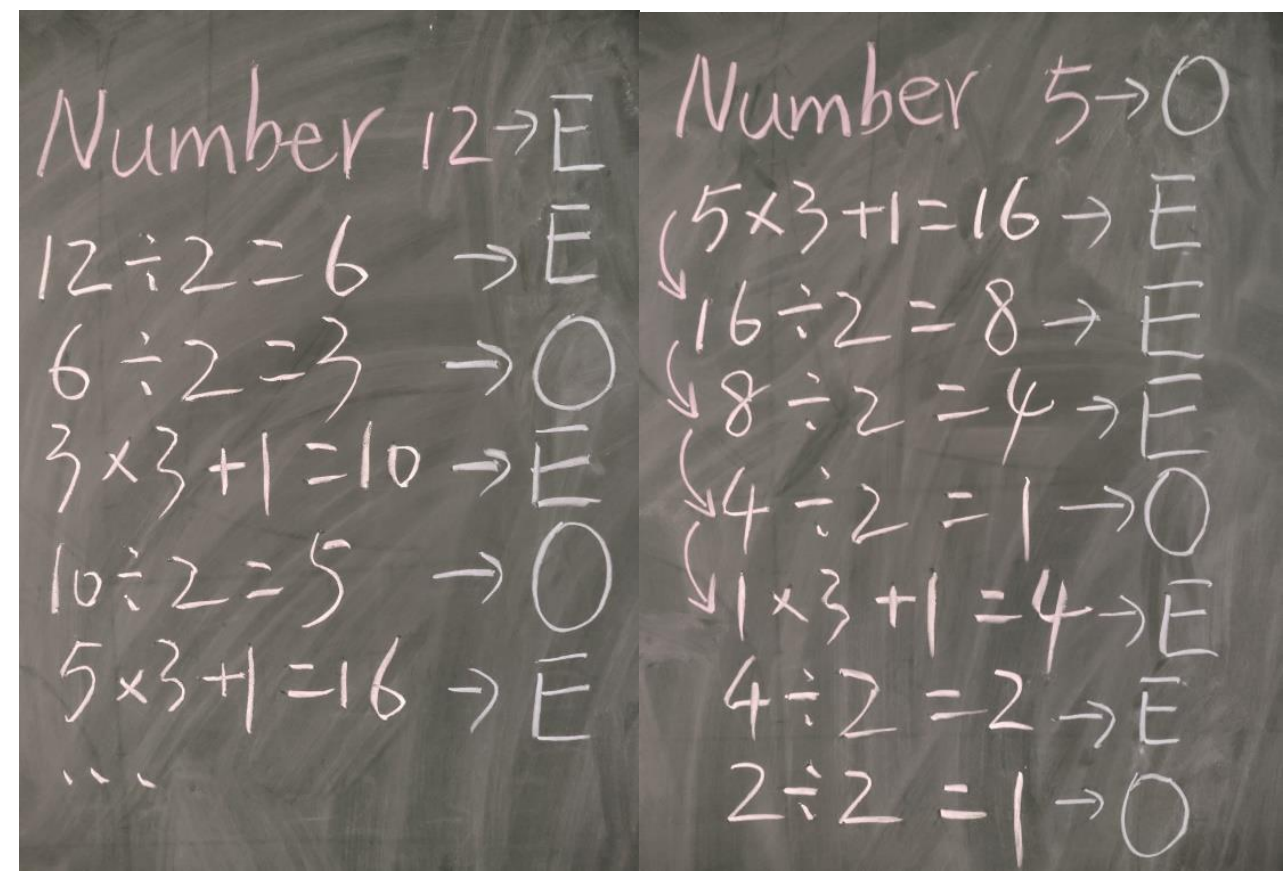

Figure 1a. E for Even number

Figure $1 b . \mathrm{O}$ for Odd number

These two pictures take the numbers "5" and "12" as examples and calculate according to the rules in the story, and the number 5 will become number 1 after multiple calculations. That is to say, The starting number is 5 , after calculation, 16 becomes 8,8 becomes 4,4 becomes 2 , half of 2 is 1,1 becomes 4 after calculation, then 4 becomes 2 again, and finally 2 returns to 1 after calculation, I am stuck in a number loop and cannot get out.

Show different questions, the final answer is 1 . Why? By showing the wonder of number operations, greatly aroused the interest of students, telling students that the number 1 is a digital black hole discovered by previous mathematicians.

The new educational goals have lowered the requirements for computing teaching (Lin, Zhou, Wang, \& Wijaya, 2020; Yi, Ying, \& Wijaya, 2019). Many students still feel that computing is boring and boring despite the decline in computing ability (Tan, Zou, Wijaya, Suci, \& Dewi, 2020; Wijaya, Zulfah, et al., 2020). In order to enhance students' interest in computing learning, a special interest in mathematical culture is carried out. Calculation games make students feel the wonders of calculation. The teacher asks the student, 1). What is a digital black hole? 2). How is the three-digit number black hole 495 obtained? What are the rules to follow when calculating? 3). Can you still find those digital black holes? How to verify?

In order to promote students' interest in computing, make computing interesting, and then proficient in the calculation skills of correct calculation; through purposeful cooperative learning, 
students can further learn to cooperate with others and realize the advantages of cooperative learning; through search Data, preliminary understanding, and then the conjecture-verification and the process of drawing conclusions, and experience the origin of mathematical conclusions.

The conversation opening in the teaching process

Teacher: Classmates, everyone in life has their own charm. The better your quality and knowledge, the more attractive you will be, and you will have a strong attraction to others. Admire and envy, and then become An example for students to learn! What is the name of the most attractive celestial body in the universe? (Blackhole) The teacher shows the relevant pictures of the black hole to the students.

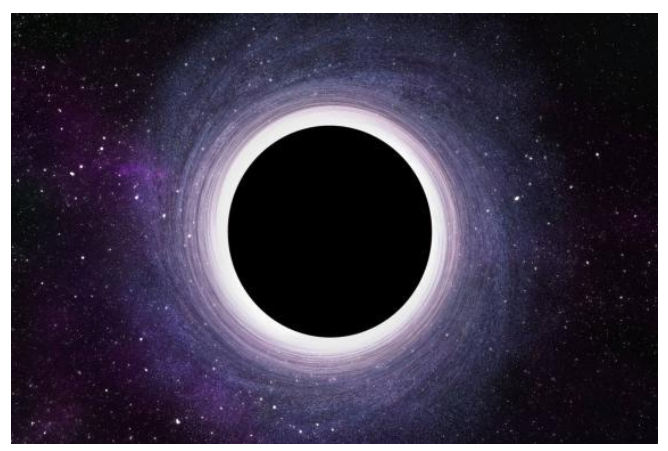

Figure 2. black hole

the first picture of a black hole taken by humans. The black part is the "shadow" cast by the black hole, and the bright part is the sucker rotating at high speed around the black hole. the attraction of black holes to nearby matter and even light will be sucked in by the black hole.

The main section in the teaching process to learn new knowledge

Teacher: Who will introduce what a black hole is?

Student 1: In the universe, there is such an extremely mysterious celestial body called "black hole". Its gravitational force is strong, and any matter passing near it must be attracted by it and never come out again. In mathematics, black holes are used to illustrate an inescapable result or destiny.

Teacher: The answer is very good. The black hole will attract everything around it, and even the light will not escape. So what is a digital black hole?

Student 2: Mathematics black hole refers to a certain kind of operation. This kind of operation is generally limited to starting from certain integers. After a finite number of operations, the result will inevitably fall into one point or several points.

Teacher: So do you understand what one point or several points mean?

Student 3: Number 1 is a digital black hole, which is one point, and 495 is three points.

So what is the rule for the three-digit number 495 black hole you studied?

Student 4: As long as you enter a three-digit number, the ones, tens, and hundreds of digits are 
required to be different, but numbers like 111 and 222 are not allowed. Next, rearrange the three numbers that make up this three-digit number according to size, and get a new number by subtracting the largest number and the smallest number, and then rearranging them in the above manner, and then subtracting them. Finally, you will always get 495. digital. (Note: When one of the three numbers is 0 , put 0 at the top, such as 5,5 , and 0 . The largest number is 550 , and the smallest number should be 55 instead of 505).

The teacher projects this rule.

Teacher: So what should be paid attention to when forming a black hole?

Student 5: The conditions for forming a black hole are: the single digits, tens digits, and hundreds of digits are not the same, then arrange and subtract

Teacher: How to verify it?

Group cooperation of 4 students, Three team members say a number they like, and the team leader is responsible for recording. Then calculate the difference according to the rearrangement method. Stop when you think you can't.

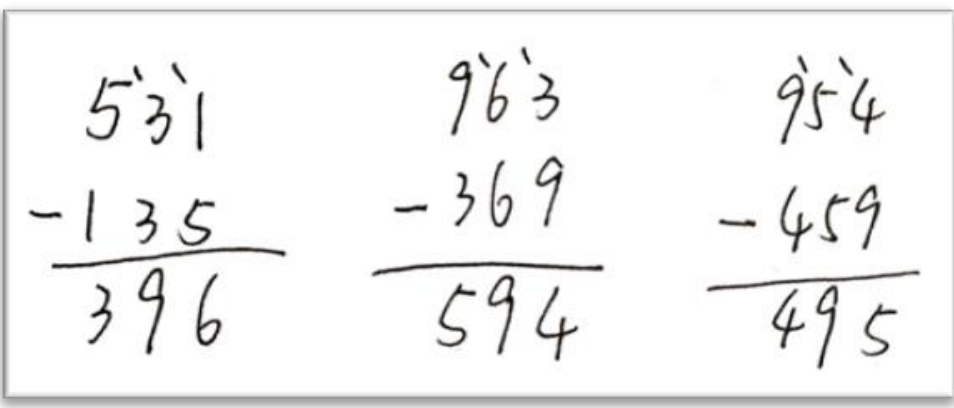

Figure 3. students' answer

Report results from student can be seen in figure 3. The student said that they use 315 for calculation, the process is as follows and According to the student's report, a mathematical conjecture can be drawn: Will the method of calculating the difference of all three-digit numbers by rearrangement get 495 ?

The second cooperation of a group of 4 students: (required) the three team members each say a number they like, and the group leader is responsible for recording. Then calculate the difference according to the rearrangement method. After counting to 495 , change three numbers and continue counting.

The teacher can explain that The three-digit gravitation of 495 is so strong that it can suck all the three-digits in again. Give 495 another name: a three-digit black hole. We once again proved that the three-digit number black hole is 495 through the method of finding the information-verifying-to reach the final conclusion.

Teacher: Have you discovered other digital black holes? What rules do they have, can you verify? 
Using “Digital Black Hole” to Help Student in Learning Arithmetic and Enhance Students' Interest in Learning, Jihe Chen, Ying Zhou Qiulian Zhao

Exploring and communicating within a group is more than one discovery than which group. Students pay attention to check whether the calculation process is correct.

Students carry out research, communication, and verification activities within the group and Which group of students report.

\section{Give Time For Students To Discuss}

Group 1: Our group found a four-digit black hole, randomly choose four different numbers to form a largest four-digit number and a smallest four-digit number, subtract the decimal number from the large number, and use the four of the result Repeat the above process for the number of bits, and finally get 6174 . And 7641-1467=6174. It seems to have fallen into a black hole and will never get out.

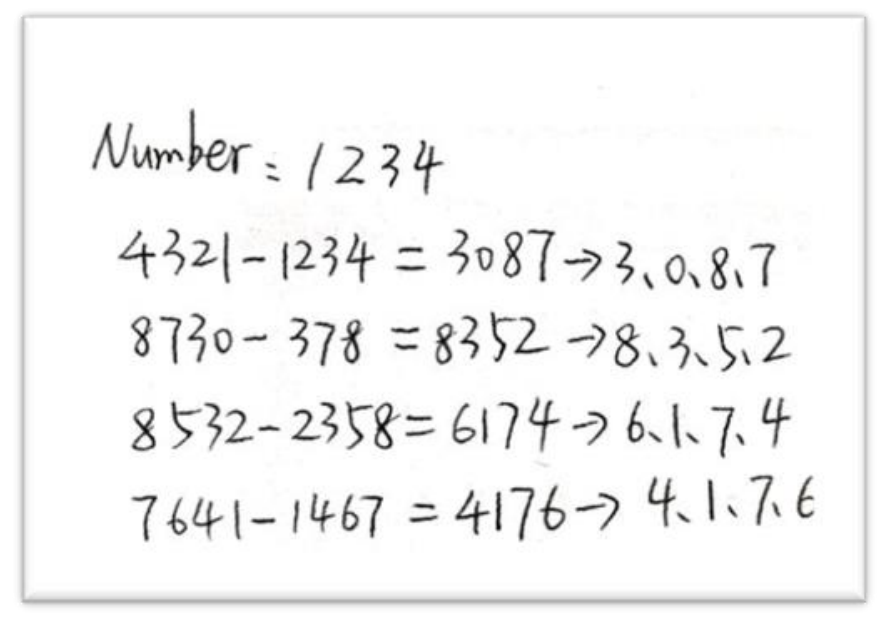

Figure 4. results of group work 1

The discussion answers from group 1 can be seen in Figure 2, they take the number 1234 as an example, carry out the calculation process of the digital black hole, and find that the four-digit digital black hole is the number "4167".

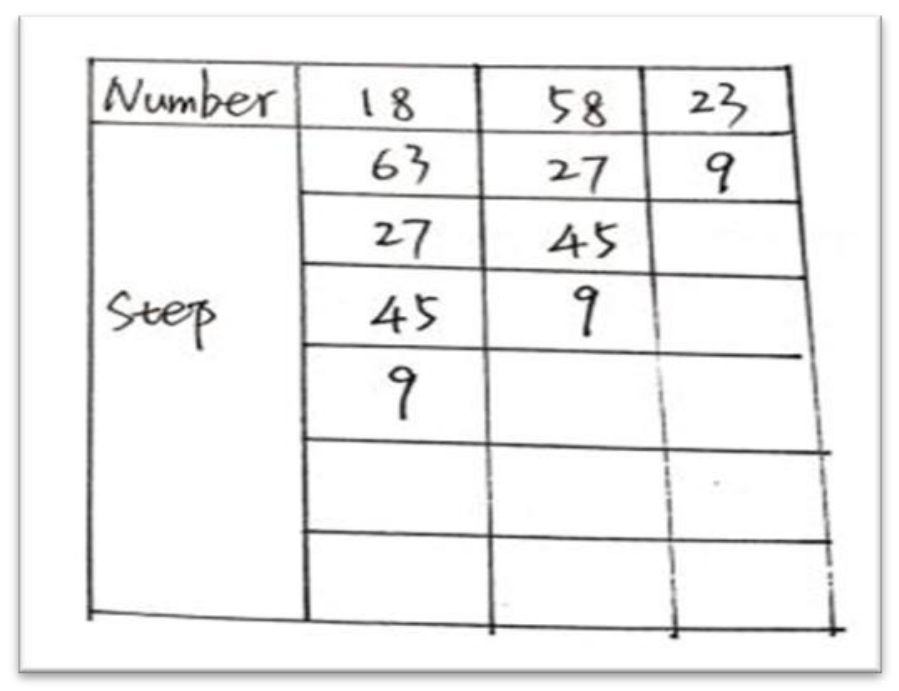

Figure 5. results of group work 2 
Take the numbers 18,58 , and 23 as examples, carry out the calculation process of digital black holes, and find that the two-digit digital black hole is the number "9"

Teacher: The students in your group are amazing! Not only has it found a four-digit black hole, but it also takes less time than checking a three-digit number! At the same time, they are displayed in the form of a table, we can see more clearly, applaud the efforts of this group! Did other students find anything else?

Group 3: The two-digit number black hole is 9

The teacher: The students did a good job. Through their own efforts, they found a two-digit and fourdigit black hole, which is very meaningful. No matter what the initial four-digit number is, it can always be counted as 6174 in the end, and once it is counted as 6174 , it will be like falling into a black hole and never jumping out again! This was discovered by the Indian mathematician Caprecar in 1949, so it is called the number of the Caprecar black hole.

The proposal of black holes in mathematics has attracted students' attention to numbers, which is much better than direct knowledge. Under the magical and beautiful mask of mathematics culture, students' interest has been greatly enhanced (Juandi \& Jupri, 2013; Tezer \& Karasel, 2010), making students' love for computing like a spring of water, making students like computing. Unconsciously, through the challenge of the digital black hole problem, a certain degree of abdicated subtraction practice was achieved, which improved the students' mathematical calculation ability, and most importantly, mobilized the students' enthusiasm for computing learning. With the help of HPM theory, students have enhanced their mathematics calculation ability, and they can also explore and discover some mathematical laws on their own, which improves classroom efficiency and teaching quality. It is worthy of our promotion.

Based on the concept of HPM, take mathematics cultural knowledge as the direction of guiding teachers' teaching concepts, instead of separating "learning" from "teaching". This shows that "education is planned, conscious, purposeful and organized learning." In this situation, teachers' attention and research on students' learning styles are very important (Nunohara et al., 2020; Syahputra \& Utami, 2019). With the development and changes of the times, we are more and more agree today that the learning process is very important. How do the children learn? What did they feel, what did they experience, and what did they realize? How do they "reach" a certain learning goal? These issues are often overlooked. Through the holistic and creative teaching characteristics, the teacher's "teaching" and the students' "learning" are linked together, starting from the basic digital black hole, to discover the law of the three-digit digital black hole, and then diverging to two digits or even The four-digit digital black hole protects and stimulates the learning potential of students and promotes their learning and growth. 


\section{CONCLUSION}

It is very important to increase students' interest in learning at the opening of class. Digital Black Hole is a simple learning media that can be used to increase student interest in learning. By using digital black holes students will not think that mathematics only talks about numbers, but mathematics also talks about the fun things that exist on earth. Suggestions for elementary mathematics teachers to continue to be creative in using learning models and media in the classroom so that elementary students like mathematics since childhood.

\section{ACKNOWLEDGEMENT}

The author would like to thank Tommy Tanu Wijaya for helping the author to complete this paper. The author would also like to thank Professor Zhou as the author's supervisor who continues to provide input and improvements to this paper. Without the help of various parties, this paper would not be perfect.

\section{REFERENCES}

Aditya, P., Wijaya, T. T., Dewi, S. N., \& Zulfah, Z. (2020). Analisis buku siswa matematika sma dari indonesia dan china pada materi peluang dan statistik. Jurnal Cendekia: Jurnal Pendidikan Matematika, 4(2), 813-822.

Angganing, P. (2011). Hubungan Antara Gaya Mengajar Guru Dan Sikap Peserta Didik Dengan Prestasi Belajar Peserta Didik Kelas 5 Di Kecamatan Wonogiri Kabupaten Wonogiri.

Bernard, M., \& Chotimah, S. (2018). Improve student mathematical reasoning ability with openended approach using VBA for powerpoint. AIP Conference Proceedings, 2014(September). https://doi.org/10.1063/1.5054417

Brezovszky, B., McMullen, J., Veermans, K., Hannula-Sormunen, M. M., Rodríguez-Aflecht, G., Pongsakdi, N., ... Lehtinen, E. (2019). Effects of a mathematics game-based learning environment on primary school students' adaptive number knowledge. Computers and Education, 128(August 2018), 63-74. https://doi.org/10.1016/j.compedu.2018.09.011

Fachrudin, A. D., Ekawati, R., Kohar, A. W., Widadah, S., Kusumawati, I. B., \& Setianingsih, R. (2019). Ancient China history-based task to support students' geometrical reasoning and mathematical literacy in learning Pythagoras. Journal of Physics: Conference Series, 1417(1). https://doi.org/10.1088/1742-6596/1417/1/012042

Feigenberg, J. (2002). Space scale: Models in the history of science and students' mental models. Science and Education, 11(4), 377-392. https://doi.org/10.1023/A:1016050526156

Franestian, I. D., Suyanta, \& Wiyono, A. (2020). Analysis problem solving skills of student in Junior High School. Journal of Physics: Conference Series, 1440(1). https://doi.org/10.1088/17426596/1440/1/012089

Izquierdo Álvarez, V. (2020). Guidelines for Instructional Design for Teaching in a Blended Learning Course. In Lecture Notes in Networks and Systems (Vol. 126). https://doi.org/10.1007/978-3030-45781-5_8

Juandi, D., \& Jupri, A. (2013). Developing Mathematical Communication and Representation of Students Grade Vii: a Design Research. Jurnal Pengajaran Matematika Dan Ilmu Pengetahuan 
Alam, 18(2), 135. https://doi.org/10.18269/jpmipa.v18i2.1

Lin, Y., Zhou, Y., Wang, S., \& Wijaya, T. T. (2020). Lesson design of geometric sequences based on the 6-question cognitive theory. Journal On Education, 02(04), 313-322.

Nunohara, K., Imafuku, R., Saiki, T., Bridges, S. M., Kawakami, C., Tsunekawa, K., ... Suzuki, Y. (2020). How does video case-based learning influence clinical decision-making by midwifery students? An exploratory study. BMC Medical Education, 20(1), 1-10. https://doi.org/10.1186/s12909-020-1969-0

Ogbonnaya, U. I. (2019). The reliability of students' evaluation of teaching at secondary school level. Problems of Education in the 21st Century, 77(1), 97-109. https://doi.org/10.33225/PEC/19.77.97

Puloo, M. M. L., Juniati, D., \& Wijayanti, P. (2018). Visualization Profile of Junior High School Students in Solving Geometry Problems Viewed from Gender Differences. Journal of Physics: Conference Series, 1108(1). https://doi.org/10.1088/1742-6596/1108/1/012063

Putri, R. I. I., \& Zulkardi. (2018). Learning fraction through the context of Asian Games 2018. Journal of Physics: Conference Series, 1088. https://doi.org/10.1088/1742-6596/1088/1/012023

Rohaeti, E.E., Nurjaman, A., Sari, I. P., Bernard, M., \& Hidayat, W. (2019). Developing didactic design in triangle and rectangular toward students mathematical creative thinking through Visual Basic for PowerPoint. Journal of Physics: Conference Series, 1157(4). https://doi.org/https://doi.org/10.1088/1742-6596/1157/4/042068

Rohaeti, Euis Eti. (2010). Critical and Creative Mathematical Thinking of Junior High School Students. Educationist, IV(2), 99-106.

Sari, D. N. O., Mardiyana, M., \& Pramudya, I. (2020). Analysis of the ability of mathematical connections of middle school students in the field of algebra. Journal of Physics: Conference Series, 1469(1). https://doi.org/10.1088/1742-6596/1469/1/012159

Siregar, N. R. (2017). Persepsi siswa pada pelajaran matematika: Studi pendahuluan pada siswa yang menyenangi Game. Prosiding Temu Ilmiah X Ikatan Psikologi Perkembangan Indonesia, 224232. Retrieved from http://jurnal.unissula.ac.id/index.php/ippi/article/view/2193

Syahputra, E., \& Utami, D. R. (2019). The design of IQF-oriented ARCS-based learning model. Journal of Physics: Conference Series, 1315(1). https://doi.org/10.1088/1742$6596 / 1315 / 1 / 012065$

Tan, S., Zou, L., Wijaya, T. T., Suci, N., \& Dewi, S. (2020). Improving student creative thinking ability with problem based learning approach using hawgent. Journal on Education, 02(04), 303-312.

Tezer, M., \& Karasel, N. (2010). Attitudes of primary school 2nd and 3rd grade students towards mathematics course. Procedia - Social and Behavioral Sciences, 2(2), 5808-5812. https://doi.org/10.1016/j.sbspro.2010.03.947

Wijaya, T. T., Tang, J., \& Purnama, A. (2020). Developing an interactive mathematical learning media based on the tpack framework using the hawgent dynamic mathematics software. In Lecture Notes of the Institute for Computer Sciences, Social-Informatics and Telecommunications Engineering, LNICST. https://doi.org/10.1007/978-3-030-60036-5_24

Wijaya, T. T., Ying, Z., Chotimah, S., Bernard, M., Zulfah, \& Astuti. (2020). Hawgent dynamic mathematic software as mathematics learning media for teaching quadratic functions. Journal of Physics: Conference Series, 1592(1). https://doi.org/10.1088/1742-6596/1592/1/012079 
Using “Digital Black Hole" to Help Student in Learning Arithmetic and Enhance Students' Interest in Learning, Jihe

Wijaya, T. T., Ying, Z., \& Purnama, A. (2020). Using Hawgent dynamic mathematics software in teaching trigonometry. International Journal of Emerging Technologies in Learning, 15(10). https://doi.org/10.3991/ijet.v15i10.13099

Wijaya, T. T., Zulfah, Z., Hidayat, A., Akbar, P., Arianti, W., \& Asyura, I. (2020). Using VBA for microsoft excel based on 6-questions cognitive theory in teaching fraction. Journal of Physics: Conference Series, 1657(1), 012078. https://doi.org/10.1088/1742-6596/1657/1/012078

Yi, L., Ying, Z., \& Wijaya, T. T. (2019). The Trend of Mathematics Teaching Method Has Change From Fragments To Systematics. Journal Cendekia: Jurnal Pendidikan Matematika, 3(2), 471480. https://doi.org/10.31004/cendekia.v3i2.137

Yuliani, T. W., Fuad, Y., \& Ekawati, R. (2019). Student's Multiple Representation in Solving Addition and Subtraction of Fraction Problem. Journal of Physics: Conference Series, 1417(1). https://doi.org/10.1088/1742-6596/1417/1/012050 